
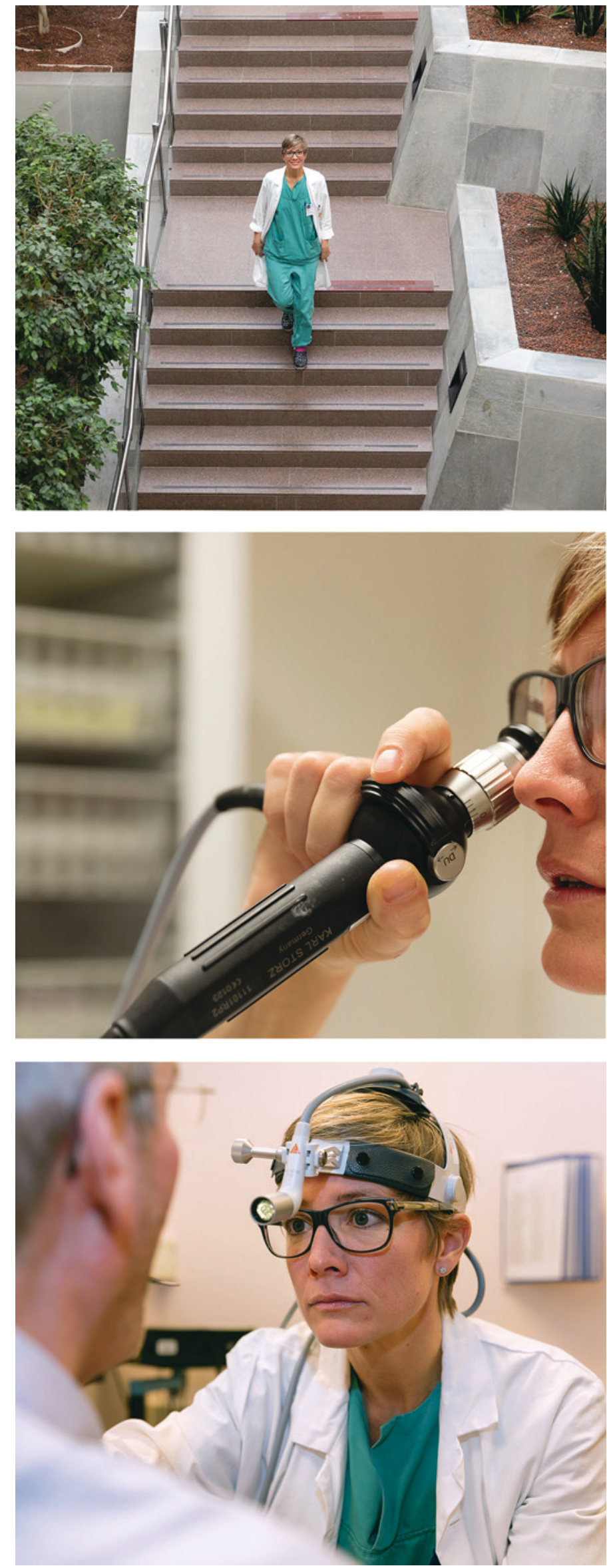

Foto: Christian Tunge

\section{HPV-infeksjonens fremtid i svelget}

\begin{abstract}
Ellen Kvestad er ph.d. og spesialist i øre-nese-halssykdommer. Hun er overlege ved onkologisk seksjon, $\emptyset$ re-nese-hals-avdelingen, Rikshospitalet.
\end{abstract}

\section{Kan du fortelle om noe viktig som skjer i faget ditt for tiden?}

Det foregår mye spennende forskning på infeksjon med humant papillomvirus (HPV) i hode-hals-onkologien nå.

Kreft i hode- og halsområdet forekommer relativt sjelden. Tobakk og alkohol har lenge vært kjente risikofaktorer for disse kreftformene. I de senere årene har forekomsten av hode-hals-kreft vært fallende, med unntak av svulster utgått fra slimhinnen i svelget (plateepitelkarsinom). Det rapporteres om økt forekomst av denne kreftformen samtidig fra flere land. Det skyldes økt forekomst av infeksjon med humant papillomvirus som forårsaker kreft i svelget. Denne forskningen har ført til at vi nå gjør HPV-analyse på alle vevsprøver fra svulster i svelget.

Studier har også vist økt overlevelse etter gjennomført behandling hos pasienter med HPV-positive svulster sammenliknet med svulster hvor HPV ikke blir funnet. I dag får alle pasienter med plateepitelkarsinom i svelget, uavhengig av svulstens HPV-status, den samme behandlingen. I fremtiden kan nye muligheter for både forebygging og behandling rettet direkte mot HPV-infeksjonen bli viktige.

\section{Kan du anbefale en ny og interessant artikkel?}

Tidsskriftet Oral Oncology hadde nylig en utgave som i sin helhet ble viet ulike aspekter HPV-infeksjon og hode-hals-kreft. I en oversiktsartikkel (1) gis det en kort oppsummering av ny kunnskap om HPV-infeksjon fra et epidemiologisk, klinisk og molekylærbiologisk perspektiv, samt forskningsspørsmål for fremtidige studier.

\section{Hva er ditt favoritthjelpemiddel på jobb?}

Jeg bruker ofte en app som henter Head \& Neck TNM Staging. Den er et lett tilgjengelig oppslagsverk for TNM-klassifisering av svulster i hode-hals-området.

\section{Anbefalt litteratur}

1. Fakhry C, Psyrri A, Chaturvedhi A. HPV and head and neck cancers: state-of-the-science. Oral Oncol 2014; 50: 353-5.

Har du tips til personer vi kan intervjue? Ta kontakt med lisa.dahlbak.jacobsen@tidsskriftet.no 